\title{
Minimal erosion of Arctic alpine topography during late Quaternary glaciation
}

\author{
Endre F. Gjermundsen ${ }^{1 \star}$, Jason P. Briner ${ }^{2}$, Naki Akçar ${ }^{3}$, Jørn Foros ${ }^{4}$, Peter W. Kubik ${ }^{5}$, Otto Salvigsen ${ }^{6}$ \\ and Anne Hormes ${ }^{1 \dagger}$
}

The alpine topography observed in many mountainous regions is thought to have formed during repeated glaciations of the Quaternary period ${ }^{1,2}$. Before this time, landscapes had much less relief $^{1-3}$. However, the spatial patterns and rates of Quaternary exhumation at high latitudes-where cold-based glaciers may protect rather than erode landscapes-are not fully quantified. Here we determine the exposure and burial histories of rock samples from eight summits of steep alpine peaks in northwestern Svalbard $\left(79.5^{\circ} \mathrm{N}\right)$ using analyses of ${ }^{10} \mathrm{Be}$ and ${ }^{26} \mathrm{Al}$ concentrations ${ }^{4,5}$. We find that the summits have been preserved for at least the past one million years. The antiquity of Svalbard's alpine landscape is supported by the preservation of sediments older than one million years along a fjord valley ${ }^{6}$, which suggests that both mountain summits and low-elevation landscapes experienced very low erosion rates over the past million years. Our findings support the establishment of northwestern Svalbard's alpine topography during the early Quaternary. We suggest that, as the Quaternary ice age progressed, glacial erosion in the Arctic became inefficient and confined to ice streams, and high-relief alpine landscapes were preserved by minimally erosive glacier armour.

Glaciers are among the most powerful eroding agents on Earth, transforming low-relief topography into over-deepened, high-relief landscapes ${ }^{7}$. The current scientific consensus is that the extensive relief characterizing much of the world's mountainous regions was generated during the Quaternary ${ }^{1,2}$. Furthermore, the height of active mountain ranges is thought to be directly influenced by the extent of glaciation through an efficient denudation mechanism whereby glacial erosion limits summit elevation above the equilibrium line altitude $e^{8,9}$. The correspondence of snowline and maximum elevation of mountain ranges has been recognized for over a century ${ }^{10}$, although whether such a relationship is governed by topographic controls on snowline altitude or erosional controls on topography has remained unsettled ${ }^{8}$. Despite growing evidence for this 'glacial buzzsaw', it remains uncertain if its effect is common to all mountain ranges ${ }^{8,11}$. For example, high-latitude ice sheets preserved pre-Quaternary continental landscapes where they were cold-based ${ }^{12,13}$. In one case even alpine topography is documented to have been armoured by cold-based ice during the Quaternary ${ }^{14}$. Here we show that glacier armour protected steep alpine summits of northwestern Svalbard during the middle and late Quaternary, implying that alpine topography in the Arctic evolved at an earlier time.
Northwestern Svalbard $\left(79^{\circ}-80^{\circ} \mathrm{N}\right.$; Fig. 1) is occupied by interconnected ice fields where spectacular contrasts in landscape exist from the coastal strandflats in the south (Mitrahalvøya) and the north (Reinsdyrflya) to tall, steep mountains in the interior. Today, $>60 \%$ of northwestern Svalbard is covered by glaciers, many of which reach adjacent seas. Mountain summits reach $>1,400 \mathrm{~m}$ above sea level (m a.s.l.) with Jäderinfjellet and Aurivilliusfjellet in the north (Fig. 2) rising to 1,150 and $1,107 \mathrm{~m}$ a.s.l., respectively, and to $1,458 \mathrm{~m}$ a.s.l. farther south with Kongen (Fig. 1). The onset of the repeated glaciations of the Svalbard Barents Sea Ice Sheet (SBIS) is recorded by the intensification of ice-rafted debris $\sim 3.5-2.4 \mathrm{Myr}$ ago on the Barents Sea margin ${ }^{15}$. During the Quaternary, the SBIS advanced to the shelf edge a number of times, and offshore moraines delimit ice sheet termini on the western Svalbard shelf ${ }^{15}$. A concept of multiple ice domes and fast-flowing ice streams separated by inter-ice-stream areas with slow-flowing or even stagnant ice during peak glacial advances has been proposed to characterize recent glaciations ${ }^{16,17}$. Evidence for ice-free areas in coastal northwestern Svalbard during the Last Glacial Maximum suggests that ice was not thick enough to bury the Svalbard archipelago completely ${ }^{18}$.

Eight alpine summits in northwestern Svalbard were sampled for ${ }^{26} \mathrm{Al} /{ }^{10} \mathrm{Be}$ burial dating ${ }^{5}$ (Figs 1 and 2 ). ${ }^{26} \mathrm{Al}$ and ${ }^{10} \mathrm{Be}$ concentrations in ten samples reflect cumulative exposure and burial; eight of ten samples show extensive burial (Fig. 3). Single nuclide ${ }^{10} \mathrm{Be}$ ages from the eight buried samples from Jäderinfjellet (1,150 $\mathrm{m}$ a.s.l.), Hornemantoppen (1,097 $\mathrm{m}$ a.s.l.; $n=2)$, Granitten (1,087 $\mathrm{m}$ a.s.l.), Aurivilliusfjellet (1,107 $\mathrm{m}$ a.s.l.), Kaffitoppen (974 $\mathrm{m}$ a.s.l.), Kjoekkensjefen (1,028 $\mathrm{m}$ a.s.l.) and Kongen (1,458 m a.s.l.) range from $41.5 \pm 2.7 \mathrm{kyr}$ to $198.6 \pm 13.0 \mathrm{kyr}$ (see Supplementary Information) and corresponding ${ }^{26} \mathrm{Al}$ ages range from $26.8 \pm 2.2$ to $121.3 \pm 8.2 \mathrm{kyr}$. The ${ }^{26} \mathrm{Al} /{ }^{10} \mathrm{Be}$ ratios range between $3.41 \pm 0.21$ and $4.53 \pm 0.23$ (Fig. 3; For complete information see Supplementary Table 2).

We calculate total minimum surface exposure histories between 0.95 and $1.63 \mathrm{Myr}$ for these eight samples. The total histories can be subdivided into minimum cumulative exposure and burial durations; exposure ranges from 0.07 to $0.4 \mathrm{Myr}$, and the summits have been shielded for a minimum of 0.78 to $1.24 \mathrm{Myr}$. These long burial durations reveal very limited erosion at most of the summits we sampled (for detailed info on single and paired maximum erosion rates see Supplementary Table 2). Two of our ten samples indicate no burial; these are from Atgeiren ( $930 \mathrm{~m}$ a.s.l.), and the second sample from Kongen (1,458 m a.s.l.; Fig. 1). Atgeiren yields a ${ }^{10} \mathrm{Be}$ age of $214.3 \pm 13 \mathrm{kyr}$, a corresponding ${ }^{26} \mathrm{Al}$ age of

\footnotetext{
${ }^{1}$ Department of Arctic Geology, The University Centre in Svalbard, PO Box 156, 9171 Longyearbyen, Norway. ${ }^{2}$ Department of Geology, University at Buffalo, Buffalo, New York 14260, USA. ${ }^{3}$ Institute of Geological Sciences, University of Bern, 3102 Bern, Switzerland. ${ }^{4}$ Charlotte Voigts veg 50,7053 Ranheim, Norway. ${ }^{5}$ Institute of Particle Physics, Swiss Federal Institute of Technology, 8093 Zurich, Switzerland. ${ }^{6}$ Department of Geosciences, University of Oslo, 0371 Oslo, Norway. †Present address: Department of Earth Sciences, University of Gothenburg, 40530 Gothenburg, Sweden.

${ }^{\star}$ e-mail: endre.gjermundsen@gmail.com
} 


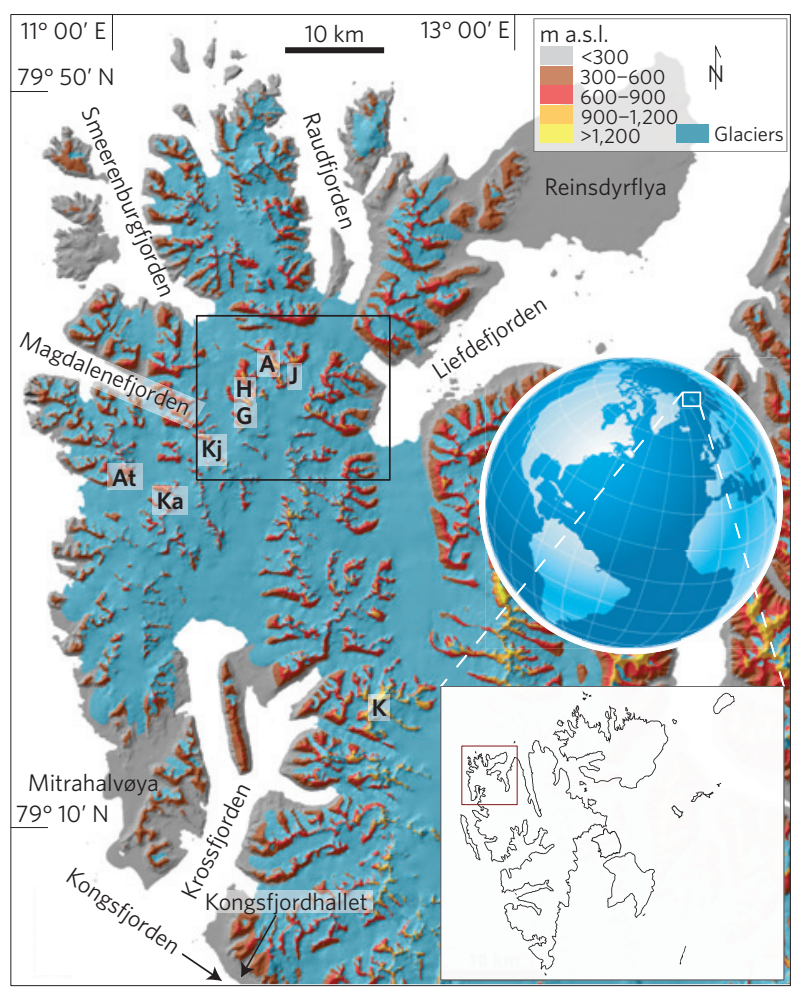

Figure 1 | Setting of northwestern Svalbard. The location of Fig. 2 is shown by the black rectangle. The two insets show Svalbard's global position and the location of northwestern Svalbard on the Svalbard archipelago. Basemap from the Norwegian Polar Institute. Blue marks the extension of today's glaciers from recent satellite imagery. $G$, Granitten; $\mathrm{H}$, Hornemantoppen; A, Aurivilliusfjellet; J, Jäderinfjellet; Kj, Kjøkkensjefen; At, Atgeiren; Ka, Kaffitoppen; K, Kongen.

$226.8 \pm 15.9 \mathrm{kyr}$, and $\mathrm{a}{ }^{26} \mathrm{Al} /{ }^{10} \mathrm{Be}$ ratio of $6.79 \pm 0.33$. The coastal location of this peak, far from the core of the northwestern Svalbard mountains, would support the indication that this peak has remained ice-free during the bulk of the middle and late Quaternary, consistent with previously published findings ${ }^{18}$. The one sample from Kongen yields a ${ }^{10} \mathrm{Be}$ age of $188.2 \pm 11.5 \mathrm{kyr}$, a corresponding ${ }^{26} \mathrm{Al}$ age of $179.1 \pm 15.4 \mathrm{kyr}$, and $\mathrm{a}^{26} \mathrm{Al} /{ }^{10} \mathrm{Be}$ ratio of $6.20 \pm 0.42$. The lack of burial in Konge- 2 could be explained by a block fall sometime during the middle Quaternary that removed previously accumulated nuclides; given the steep nature of our study summits, we find it not surprising that some of our data show evidence for sporadic mass wasting.

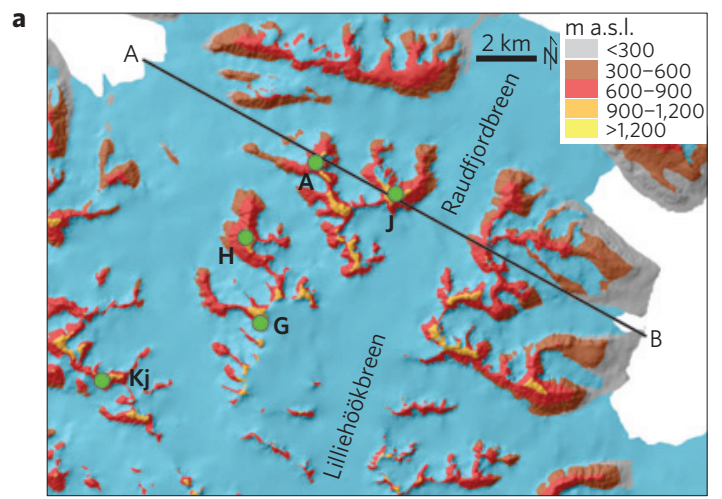

These first reported paired cosmogenic-nuclide data from alpine summits in the Arctic indicate significant antiquity and long-term burial of the seemingly fragile mountain summits. The summit ages are older than most cosmogenic-nuclide-derived ages previously reported from ice sheet landscapes elsewhere in the Northern Hemisphere, which tend to be from lower relief areas ${ }^{19,20}$ (Fig. 3). For example, minimum burial-exposure ages from interfjord landscapes of selective erosion in other Arctic environments thought to be only periodically occupied by cold-based ice are typically $0.3-0.7 \mathrm{Myr}$ (ref. 21). Thus, we find it surprising that Svalbard's summits are $0.9-1.6 \mathrm{Myr}$ old and have been eroded less than non-alpine ice sheet landscapes. Furthermore, owing to long periods of burial, the survival of alpine summits is not likely to be the result of the peaks remaining ice-free. Rather, it seems that ice sheets have cyclically occupied the landscape throughout the Quaternary, apparently without significantly modifying the alpine uplands.

In northwestern Svalbard an increase in ${ }^{10} \mathrm{Be}$ concentrations in bedrock with increasing elevation has also been found ${ }^{17}$, indicating a decrease in erosion with rising elevation in this area. Despite this finding, outcrops of beach deposits that are $>1$ Myr old along the northern shore of Kongsfjorden ${ }^{6}$ (Fig. 1), along with bedrock strandflats in the area considered to be of some antiquity ${ }^{22}$, require non-efficient glacier erosion during the latter portion of the Quaternary, even in some low-elevation areas. These data reveal complex patterns of erosion, where significant erosion is limited to only the central axes of fjords and valleys, possibly related to the location of ice stream activity ${ }^{23}$ (Fig. 4). Furthermore, offshore sedimentary data from the western Svalbard shelf indicate a decrease in glacial erosion and increase in ice streaming beginning $\sim 1 \mathrm{Myr}$ ago (ref. 24). Collectively, there is evidence from both summits and fjord valleys in northwestern Svalbard for increasing protection of alpine landscapes in the middle-to-late Quaternary.

Although basal ice conditions, topography and bedrock geology are variables that influence glacial erosion, basal thermal regime is the most $\mathrm{critical}^{23}$. We propose that the ice occupying the summits of northwestern Svalbard became predominantly cold-based, and minimally erosive, as the Quaternary ice age progressed (Fig. 4), possibly accompanied by increased ice streaming and ice sheet drawdown. We infer that northwestern Svalbard transitioned from a glacier-erosion state with relief generation due to warm-based glacier incision of the valleys under relatively mild glacial maxima temperatures, to a state of glacier armour with more extensive occupation by polythermal and cold-based, protective ice in the middle and late Quaternary during much colder glacial maxima temperatures, where only the central axes of valleys continued to be carved by warm-based portions of ice sheets (Fig. 4). Relief generation may have been further inhibited owing to a

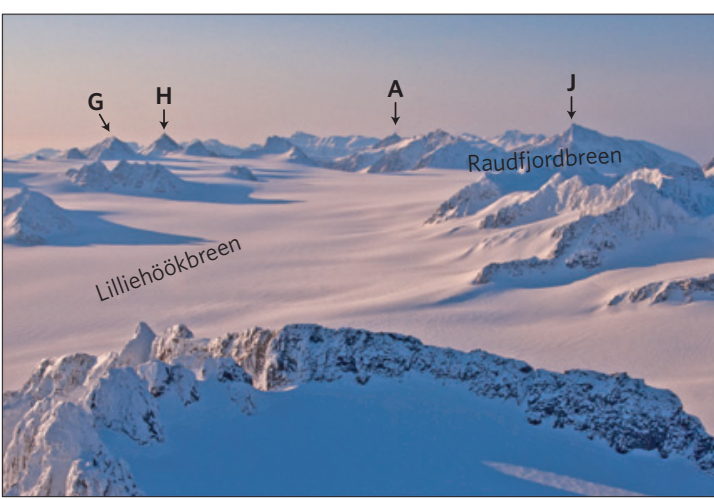

Figure 2 | Sample locations and northwestern Svalbard landscape. a, Sample locations (green circles); map location shown in Fig. 1, with the location of the topographic profile (A-B) used in Fig. 4. b, Photograph illustrating alpine topography of northwestern Svalbard with four of the sampled mountains. Abbreviations as in Fig. 1. 


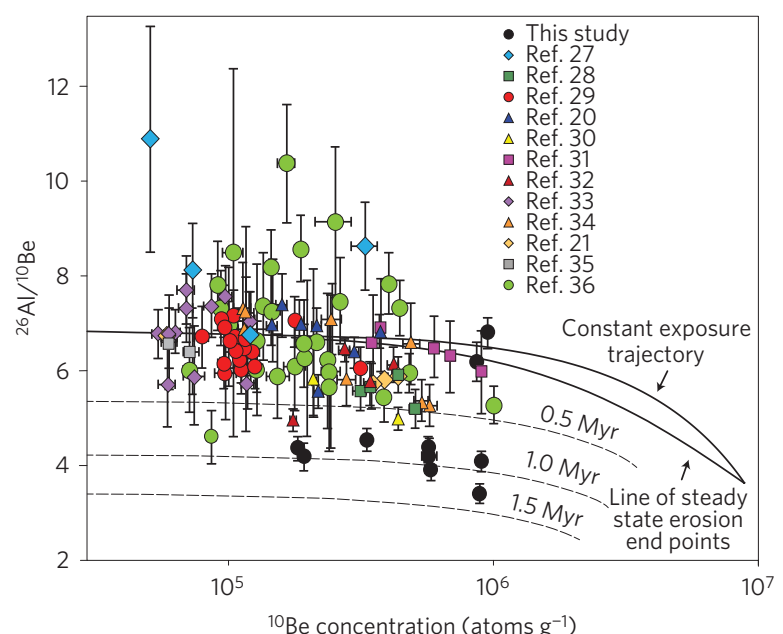

Figure 3 | Plot of ${ }^{26} \mathrm{~A} /{ }^{10} \mathrm{Be}$ ratios. Plot of ${ }^{26} \mathrm{~A} /{ }^{10} \mathrm{Be}$ ratios from Europe and Greenland compared to our results from northwest Svalbard (black circles). References given in Supplementary Information. ${ }^{10} \mathrm{Be}$ concentrations are normalized to sea level. Samples plotting below the steady state curve contain inheritance; dashed lines are burial isochrones with corresponding burial durations. transition to a permafrost regime with a thin to non-existent active layer that protected summits (when exposed) against erosion ${ }^{25}$. In any case, the alpine topography of northwestern Svalbard, and perhaps elsewhere in the Arctic, was evolving under glacial erosion conditions before $0.9-1.6 \mathrm{Myr}$ ago. The transition coincides with the mid-Pleistocene transition from 41 to $100 \mathrm{kyr}$ glacier $\mathrm{cycles}^{26}$. This conceptual model for landscape development may apply to landscape evolution throughout the polar regions on Earth.

Our results provide a point of view different than that developed from studies of mountain regions at lower latitudes, such as from the European Alps, where the present morphology is considered to be strongly influenced by middle and late Quaternary glaciations ${ }^{2}$. This is in contrast to northwestern Svalbard, where the alpine landscape seems to have been preserved through the same period.

We propose that as high-latitude alpine glaciation and climate evolved, erosion became confined to ice stream locations, and much of the landscape (even steep alpine summits and some valley bottom locations) became protected from erosion by an armour of nonerosive ice (Fig. 4). We argue that the importance of glaciers as an armouring agent versus being efficient eroding agents in polar alpine landscapes varies through both time and space, depending on glacier regime, and that even steep alpine landscapes, such as on Svalbard, can be protected. The development of large ice sheets after the mid-Pleistocene transition could have played a role in a regime

a

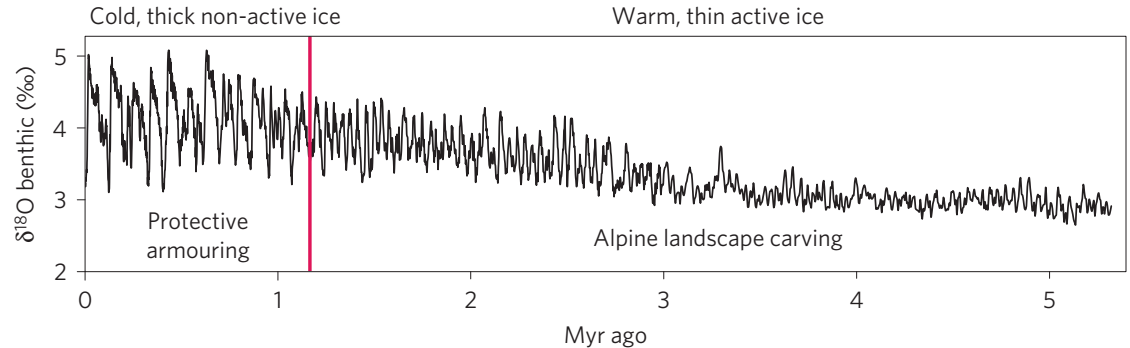

\section{b}

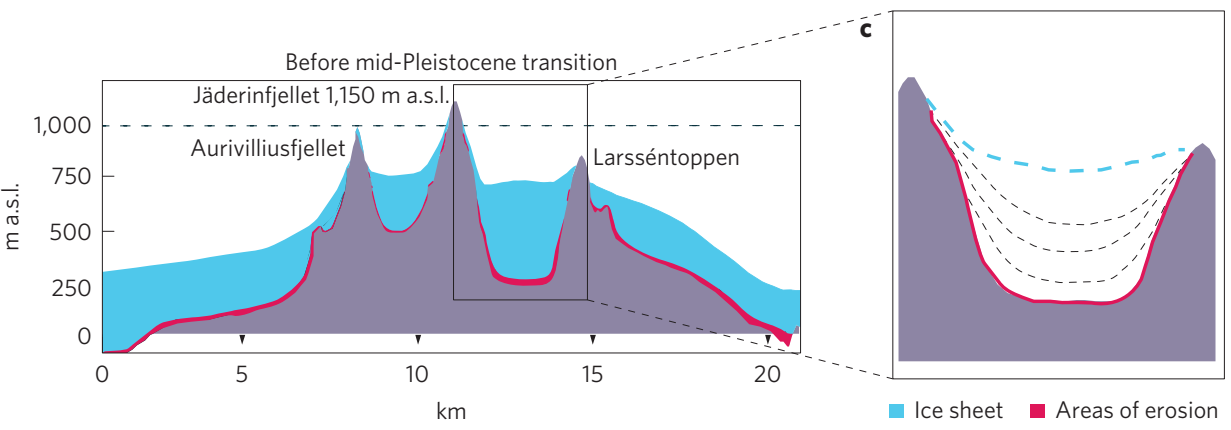

d

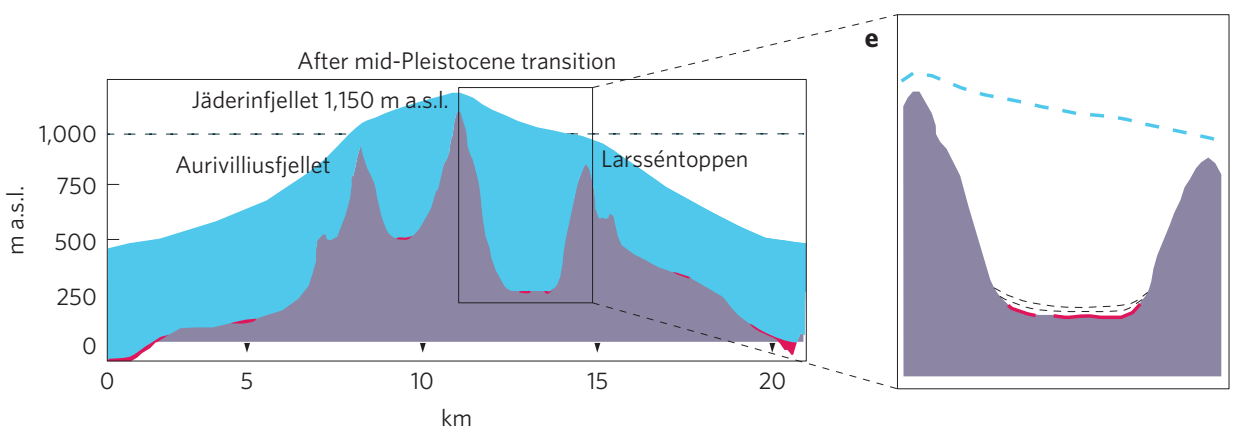

Figure 4 | Conceptual model of transition to glacial armouring. a, Fluctuations in global benthic $\delta^{18} \mathrm{O}$ for the past $5 \mathrm{Myr}$ (ref. 25). b-e, Profile from Fig. 2a with two different glacier scenarios throughout the Pleistocene. Changes from 41 kyr towards 100 kyr glacier cycles (mid-Pleistocene transition; red line in a) represent changes in environment from warm-bedded, thin active ice resulting in alpine landscape carving under conditions of relatively mild glacial maxima ( $\mathbf{b}$ and $\mathbf{c}$ ), to thicker and cold-bedded phases with protective armouring ice under condition of colder glacier maxima (d and $\mathbf{e}$ ). The stippled blue line in $\mathbf{c}$ and $\mathbf{e}$ indicate the glacier surface, whereas the black lines indicate lowering of the topography. 
shift of Arctic glaciers from one of erosion to one of protection, which may have played a significant role in landscape evolution at the poles.

\section{Methods}

Methods and any associated references are available in the online version of the paper.

\section{Received 24 November 2014; accepted 3 August 2015;} published online 16 September 2015

\section{References}

1. Montgomery, D. R. Valley formation by fluvial and glacial erosion. Geology 30, 1047-1050 (2002).

2. Norton, K. P., Abbuehl, L. M. \& Schlunegger, F. Glacial conditioning as an erosional driving force in the Central Alps. Geology 38, 655-658 (2010).

3. Kleman, J. \& Stroeven, A. P. Preglacial surface remnants and Quaternary glacial regimes in northwestern Sweden. Geomorphology 19, 35-54 (1997)

4. Balco, G., Stone, J. O., Lifton, N. A. \& Dunai, T. J. A complete and easily accessible means of calculating surface exposure ages or erosion rates from ${ }^{10} \mathrm{Be}$ and ${ }^{26} \mathrm{Al}$ measurements. Quat. Geochronol. 3, 174-195 (2008).

5. Bierman, P. R., Marsella, K. A., Patterson, C., Davis, P. T. \& Caffee, M. Mid-Pleistocene cosmogenic minimum-age limits for pre-Wisconsinan glacial surfaces in southwestern Minnesota and southern Baffin island: A multiple nuclide approach. Geomorphology 27, 25-39 (1999).

6. Houmark-Nielsen, M. \& Funder, S. Pleistocene stratigraphy of Kongsfjordhallet, Spitsbergen, Svalbard. Polar Res. 18, 39-49 (1999).

7. Hallet, B., Hunter, L. \& Bogen, J. Rates of erosion and sediment evacuation by glaciers: A review of field data and their implications. Glob. Planet. Change 12, 213-235 (1996)

8. Mitchell, S. G. \& Montgomery, D. R. Influence of a glacial buzzsaw on the height and morphology of the Cascade Range in central Washington State, USA. Quat. Res. 65, 96-107 (2006).

9. Egholm, D. L., Nielsen, S. B., Pedersen, V. K. \& Lesemann, J. E. Glacial effects limiting mountain height. Nature 460, 884-887 (2009).

10. Mills, J. E. Stratigraphy and succession of the rocks of the Sierra Nevada of California. Geol. Soc. Am. 3, 413-444 (1892).

11. Hall, A. M. \& Kleman, J. Glacial and periglacial buzzsaws: Fitting mechanisms to metaphors. Quat. Res. 81, 189-192 (2014).

12. Hall, A. M. \& Sugden, D. E. Limited modification of mid-latitude landscapes by ice sheets: The case of northeast Scotland. Earth Surf. Process. Landf. 12, 531-542 (1987)

13. Kleman, J. Preservation of landforms under ice-sheets and ice caps. Geomorphology 9, 19-32 (1994)

14. Thomson, S. N. et al. Glaciation as a destructive and constructive control on mountain building. Nature 467, 313-317 (2010).

15. Jakobsson, M. et al. Arctic Ocean glacial history. Quat. Sci. Rev. 92, 40-67 (2014).

16. Landvik, J. Y. et al. Landscape imprints of changing glacial regimes during ice-sheet build-up and decay: A conceptual model from Svalbard. Quat. Sci. Rev. 92, 258-268 (2014)

17. Gjermundsen, E. F. et al. Late Weichselian local ice dome configuration and chronology in Northwestern Svalbard: Early thinning, late retreat. Quat. Sci. Rev. 72, 112-127 (2013).

18. Landvik, J. Y. et al. Northwest Svalbard during the last glaciation: Ice-free areas existed. Geology 31, 905-908 (2003).

19. Fabel, D. et al. Landscape preservations under Fennoscandian ice sheets determined from in situ produced ${ }^{10} \mathrm{Be}$ and ${ }^{26} \mathrm{Al}$. Earth Planet. Sci. Lett. 201, 397-406 (2002).

20. Glasser, N. F., Hughes, P. D., Fenton, C., Schnabel, C. \& Rother, H. ${ }^{10}$ Be and ${ }^{26} \mathrm{~A}$ exposure-age dating of bedrock surfaces on the Aran ridge, Wales: Evidence for a thick Welsh Ice Cap at the Last Glacial Maximum. J. Quat. Sci. 27, 97-104 (2012)

21. Stroeven, A. P., Fabel, D., Hattestrand, C. \& Harbor, J. A relict landscape in the centre of Fennoscandian glaciation: Cosmogenic radionuclide evidence of tors preserved through multiple glacial cycles. Geomorphology 44, 145-154 (2002).
22. Nansen, F. The Strandflat and Isostasy (Vitenskapsselskapets Skrifter I. Matematisk-Naturvitenskapelig Klasse No. II)1-313 (A. W. Brøggers Boktrykkeri, 1922).

23. Sugden, D. E. Glacier erosion by the Laurentide Ice Sheet. J. Glaciol. 20, 367-391 (1978)

24. Solheim, A., Andersen, E. S., Elverhøi, A. \& Fiedler, A. Late Cenozoic depositional history of the western Svalbard continental shelf, controlled by subsidence and climate. Glob. Planet. Change 12, 135-148 (1996).

25. Etzelmüller, B. \& Frauenfelder, R. Factors controlling the distribution of mountain permafrost in the northern hemisphere and their influence on sediment transfer. Arctic Antarct. Alpine Res. 41, 48-58 (2009).

26. Raymo, M. E., Lisiecki, L. E. \& Nisancioglu, K. H. Plio-Pleistocene ice volume, Antarctic climate, and the global $\delta^{18} \mathrm{O}$ record. Science 313, 492-495 (2006).

27. Brook, E. J., Nesje, A., Lehman, S., Raisbeck, G. \& Yiou, F. Cosmogenic nuclide exposure ages along a vertical transect in western Norway: Implications for the height of the Fennoscandian ice sheet. Geology 24, 207-210 (1996).

28. Darmody, R. G. et al. Age and weathering status of granite tors in Arctic Finland (similar to 68 degrees N). Geomorphology 94, 10-23 (2008).

29. Fabel, D. et al. Landscape preservations under Fennoscandian ice sheets determined from in situ produced ${ }^{10} \mathrm{Be}$ and ${ }^{26} \mathrm{Al}$. Earth Planet. Sci. Lett. 201, 397-406 (2002).

30. Harbor, J. et al. Cosmogenic nuclide evidence for minimal erosion across two subglacial sliding boundaries of the late glacial Fennoscandian ice sheet. Geomorphology 75, 90-99 (2006).

31. Håkansson, L. et al. Late Pleistocene glacial history of Jameson Land, central East Greenland, derived from cosmogenic ${ }^{10} \mathrm{Be}$ and ${ }^{26} \mathrm{Al}$ exposure dating. Boreas 38, 244-260 (2009).

32. Li, Y., Fabel, D., Stroeven, A. P. \& Harbor, J. Unraveling complex exposure-burial histories of bedrock surfaces under ice sheets by integrating cosmogenic nuclide concentrations with climate proxy records. Geomorphology 99, 139-149 (2008).

33. Roberts, D. H., Long, A. J., Schnabel, C., Freeman, S. \& Simpson, M. J. R. The deglacial history of southeast sector of the Greenland Ice Sheet during the Last Glacial Maximum. Quat. Sci. Rev. 27, 1505-1516 (2008).

34. Stone, J. O., Ballantyne, C. K. \& Fifield, L. K. Exposure dating and validation of periglacial weathering limits, northwest Scotland. Geology 26, 587-590 (1998).

35. Stroeven, A. P. et al. Importance of sampling across an assemblage of glacial landforms for interpreting cosmogenic ages of deglaciation. Quat. Res. 76, 148-156 (2011)

36. Phillips, W. M., Hall, A. M., Mottram, R., Fifield, L. K. \& Sugden, D. E. Cosmogenic ${ }^{10} \mathrm{Be}$ and ${ }^{26} \mathrm{Al}$ exposure ages of tors and erratics, Cairngorm Mountains, Scotland: Timescales for the development of a classic landscape of selective linear glacial erosion. Geomorphology 73, 222-245 (2006).

\section{Acknowledgements}

Financial support was provided by internal UNIS funding to E.F.G., the ConocoPhillips/Lundin Northern Area Program and internal UNIS funding to A.H. and Arctic Field Grants from Svalbard Science Forum/Norwegian Research Council (ris ID 2801/364). Logistical support was provided by UNIS and the AWIPEV base run by the Alfred-Wegener Institute for Polar and Marine Research and the Institut Polaire Français Paul Emile Victor (IPEV). We sincerely thank our field assistants H. Dannevig, J. Fjellanger, T. Hipp, H. Kaasin, C. P. Nielsen, B. A. Skjæret and T. Snøtun. We thank our sponsors (see http://www.icebound.no). We acknowledge comments on earlier drafts from D. Benn, B. Etzelmüller, O. Ingólfsson, J. O. Hagen, M. Kelly and J. Mangerud.

\section{Author contributions}

A.H. initiated this research. E.F.G. and A.H. collected the field data and prepared rocks for cosmogenic radionuclide dating. N.A. chemically prepared the samples for ${ }^{10} \mathrm{Be}$ and ${ }^{26} \mathrm{Al}$ measurements. P.W.K. performed AMS measurements. E.F.G., J.P.B., A.H. and O.S. interpreted the data. J.F. assisted with the calculations. E.F.G., J.P.B. and A.H. wrote the manuscript.

\section{Additional information}

Supplementary information is available in the online version of the paper. Reprints and permissions information is available online at www.nature.com/reprints. Correspondence and requests for materials should be addressed to E.F.G.

\section{Competing financial interests}

The authors declare no competing financial interests. 


\section{Methods}

Samples for cosmogenic ${ }^{26} \mathrm{Al}$ and ${ }^{10} \mathrm{Be}$ analysis were collected from bedrock surfaces on the summits of some of the highest peaks in northwestern Svalbard. Samples were collected from windswept locations in spring (the time of maximum seasonal snow cover) to ensure that sample sites remained snow-free year round. Elevation, latitude and longitude data were gathered with a handheld global positioning system (GPS). Topographic shielding was measured using an inclinometer and calculated using the scaling factors given in Dunne and colleagues ${ }^{37}$. For validation we compared the correction factor to the correction factor gained from an automatic generated technique described by Codilean ${ }^{38}$, using a digital elevation model in ArcMap. Samples were not corrected for isostatic rebound because the amplitude of change during the past million years has been low $^{6}$. Samples were processed at the Institute of Geological Sciences, University of Bern for the accelerator mass spectrometry (AMS) measurements of ${ }^{10} \mathrm{Be} /{ }^{9} \mathrm{Be}$ and ${ }^{26} \mathrm{Al} /{ }^{27} \mathrm{Al}$ at the ETH/PSI tandem facility in Zürich. ${ }^{10} \mathrm{Be}$ and ${ }^{26} \mathrm{Al}$ ages were calculated using the CRONUS online exposure age calculator ${ }^{4}$ using the ${ }^{10} \mathrm{Be}$ production rate from
Northern Norway ${ }^{39}$ (see Supplementary Information for details). Minimum burial and exposure ages and maximum erosion rates were calculated from our ${ }^{10} \mathrm{Be}$ and ${ }^{26} \mathrm{Al}$ concentrations using the Excel add-in CosmoCalc ${ }^{40}$.

\section{References}

37. Dunne, J., Elmore, D. \& Muzikar, P. Scaling factors for the rates of production of cosmogenic nuclides for geometric shielding and attenuation at depth on slope surfaces. Geomorphology 27, 3-11 (1999).

38. Codilean, A. T. Calculation of the cosmogenic nuclide production topographic shielding scaling factor for large areas using DEMs. Earth Surf. Process. Landf. 31, 785-794 (2006).

39. Fenton, C. R. et al. Regional ${ }^{10} \mathrm{Be}$ production rate calibration for the past $12 \mathrm{ka}$ deduced from the radiocarbon-dated Grøtlandsura and Russenes rock avalanches at $69^{\circ} \mathrm{N}$, Norway. Quat. Geochronol. 6, 437-452 (2011).

40. Vermeesch, P. CosmoCalc: An Excel add-in for cosmogenic nuclide calculations. Geochem. Geophys. Geosyst. 8, Q08003 (2007). 